\title{
Струве, retractationes
}

КОЛЕРОВ М. А. (2020). ПЕТР СТРУВЕ: РЕВОЛЮЦИОНЕР БЕЗ МАСС, 1870-1918. ПРИЛОЖЕНИЕ: НОВОЕ СОБРАНИЕ СОЧИНЕНИЙ П. Б. СТРУВЕ (1903-1917). М.: КНИЖНЫЙ МАГАЗИН ЩЦИОЛКОВСКИЙУ. 464 С. ISBN 978-5-6043673-3-9

\author{
Андрей Тесля \\ Кандидат философских наук, старший научный сотрудник, \\ научный руководитель (директор) Центра исследований русской мысли, \\ Институт гуманитарных наук, Балтийский федеральный университет \\ имени Иммануила Канта \\ Адрес: ул. Чернышевского, д. 56, г. Калининград, Российская Федерация 236016 \\ E-mail: mestr81@gmail.com
}

«Новая биография П. Б. Струве. 1870-1918», как озаглавлена первая часть книги M. А. Колерова ${ }^{1}$, уже потому заслуживает пристального интереса, что подводит итог более чем тридцатилетней работе автора над этой темой. Биография Струве, написанная Колеровым, содержит массу частных находок, деталей, уточнений известного - и ценный свод предшествующих исследований, в первую очередь публиковавшихся в «Ежегоднике по истории русской мысли». При этом множество любопытнейшей информации, как библиографического, так и содержательного плана, отнесено в примечания - так, например, примечание 9 к гл. 3-й (с. 451) является кратким очерком истории понятия «усложнение жизни» в работах Струве и завершается отсылкой к соответствующему понятию в «Государстве и революции» Ленина.

Однако основная ценность данной работы, придающая отдельным находкам и наблюдениям смысл, далеко выходящий за сугубо историографический, в критической переоценке расхожих схем и интерпретаций русской интеллектуальной истории 1890-1910-х годов. Как отмечает сам автор в предпосланном его труду историографическом введении, основные схемы интерпретации были созданы самими героями или их младшими современниками: масштабные исторические труды, такие как «История русской философии» В. В. Зеньковского (1-е изд.: 1948-1950) или Н. О. Лосского (1-е англ. изд.: 1951, рус.: 1991), «Истоки и смысл русского коммунизма» (1-е англ. изд.: 1937, рус.: 1955) и «Русская идея» (1946) Н. А. Бер-

* Работа выполнена в рамках гранта РНФ (№ 18-18-оо442) «Механизмы смыслообразования и текстуализации в социальных нарративных и перформативных дискурсах и практиках» в Балтийском федеральном университете имени И. Канта.

1. Вторая часть книги представляет собой собрание ранее не переиздававшихся текстов Струве, в том числе написанных им до сборника «Patriotica» (1911), но по тем или иным причинам не включенным в него - и представляющим потому особенный интерес, как характеризующие его интеллектуальные поиски 19о0-х годов, в конце концов сочтенные им самим неверными или неактуальными к 1911 года. 
дяева, «Пути русского богословия» Г. В. Флоровского $(1938)^{2}-$ создают «общепринятый рукотворный образ русской философии» (с. 8). Распространенная интерпретация интеллектуальной биографии Струве, по справедливой оценке исследователя, предстает в первую очередь воспроизводством осуществленного им самим «историософского „пересоздания“ своей жизни» (Там же), в свою очередь, бережно сохраненного и систематизированного в биографии-мемуаре, написанном С. Л. Франком ${ }^{3}$, на протяжении десятилетий одного из ближайших к Струве людей.

Так, обращаясь к первой половине 1890-х, Колеров подробно раскрывает смысл полемики, связанной с «Критическими заметками...» Струве (1894), — не как спор между марксистами и народниками, а заключающийся в переинтерпретации марксизма применительно к России, поскольку с 1870-х годов марксизм вполне усвоен народничеством. Это, отметим попутно, ставит вопрос о настоятельной необходимости «другой» истории русского марксизма в рамках интеллектуальной истории - где марксизм как русского народничества, так и неонародничества будет осмыслен уже не как маргинальная ветвь по отношению к линии, ведущей от группы «Освобождение труда» к социал-демократическим кружкам 1890-х и далее к РСДРП.

В контекстуализации, отказе от ретроспективного взгляда (когда известны дальнейшие линии эволюции, известны результаты, к которым придут конкретные персонажи, а также какие из идей и их интерпретаций возобладают в дальнейшем) - состоит исследовательский метод Колерова. Так, если не только социал-демократические оппоненты Струве, но и сам Струве в дальнейшем были склонны пользоваться понятием «легального марксизма» (для социал-демократических оппонентов, в частности Ленина, это был инструмент дискредитации оппонента в глазах радикальной общественности, для Струве в рамках той все более «правеющей» системы взглядов, которая становилась ему присущей с 1905 года - как инструмент обоснования своего раннего отхода, дистанцирования от русской социал-демократии), то в исследовательской оптике Колерова это не только понятие позднейшего, по отношению к обозначаемым им процессам, происхождения, но и само по себе является орудием политической борьбы. Лишь затемняющим реальные интеллектуальные процессы, протекавшие в последние годы 1890-х и в начале 1900-х годов, когда ни для тех, кто в дальнейшем обозначался как «легальные марксисты» (их участие в легальных изданиях не означало отказа от иных форм политической борьбы), ни для тех, кто обозначал себя в дальнейшем от обратного, не означало отказа от любых возможных форм легальной деятельности. Еще в рамках подготовки II (Лондонского) съезда РСДРП в 1903 году предполагается приглашение в числе участников и Струве. До установления партий-

2. Как и «Краткий курс истории ВКП(б)» (1938).

3. Франк С. Л. (2001). Воспоминания о П. Б. Струве // Франк С. Л. Непрочитанное... Статья, письма, воспоминания / Сост. А. А. Гапоненкова, Ю. П. Сенокосова. М.: Московская школа политических исследований. 
ной ортодоксии и выстраивания жестких границ еще достаточно далеко и Струве не воспринимается как принципиально находящийся за пределами партии, в это время в рамках «Освобождения» выстраивающей широкую коалицию социалистов и либералов против существующего режима.

Еще более значимым является детальное реконструирование деятельности Струве по возвращении из эмиграции в 1905 году, когда Колеров демонстрирует существенную роль социал-демократического наследия в его взглядах 1906 года. В дальнейшем, в первую очередь в эмиграции, существенно поправев и сделавшись, в частности, монархистом, Струве будет «выпрямлять» свой интеллектуальный путь, стараясь игнорировать длинный след социалистических идей, но обращение к текстам и издательским проектам Струве второй половины 190о-х демонстрирует, что разрыв не был радикален (что вполне предсказуемо, в том числе и с учетом во многом социалистической программы конституционно-демократической партии ${ }^{4}$. Напомним, что и само «идеалистическое» направление в русской мысли начала 1900-х («Проблемы идеализма», 1902), лидером которого был Струве, стремилось найти новые философские основания для социал-демократии ${ }^{5}$. Последующее движение «к церкви», представляющее этот путь целостным, является существенно более поздней ретроспекцией. Аналогично в ретроспективе окажется практически забытым противостояние 1907-1914 годов Струве с Мережковским и его кругом, часть которого - история «Вех», в понимании Струве противостоящих программе, выраженной в сборнике Мережсковского, Гиппиус и Философова «Царь и революция» $(1907)^{6}$. Если для круга Мережковского речь идет о революционном потенциале христианства - возможности нового религиозного движения (Третьего Завета), то Струве, в отличие от целого ряда близких к нему интеллектуалов (напр., С. Н. Булгакова), в эти годы утверждает религиозный индивидуализм как описание фактического положения дел, уход религии как фактора общественной мобилизации ${ }^{7}$.

Из числа же вызывающих сомнения моментов в работе Колерова отметим констатацию «полного разочарования [Струве в 1914 г.] в германской социал-демократии, поддержавшей германский милитаризм» (с. 250, ср.: с. 234-237). По крайней мере приводимые самим исследователем сведения не дают, на наш взгляд, возможности для столь радикального вывода - что в этом Струве подвел «итог своему идейному социализму как отражению и применению в России его германского образца» (с. 237), поскольку основанием для этого вывода служит публицистика

4. См., в частности: Гайда Ф. А. (2016). Власть и общественность в России: диалог о пути политического развития (1910-1917). М.: Русский фонд содействия образованию и науке.

5. Колеров M. A. (2002). Idealismus militans: история и общественный смысл сборника «Проблемы идеализма» // Проблемы идеализма. Сборник статей [1902] / Под ред. М. А. Колерова, подгот. текста Н. В. Самовер. М.: Модест Колеров и «Три квадрата». С. 61-224.

6. Колеров М. А. (1996). Не мир, но меч: русская религиозно-философская печать от «Проблем идеализма» до «Вех». 1902-1909. СПб.: Алетейя.

7. См., в частности: Teslya A. (2019). The Protestant Ethic in the Russian Context: Peter Struve and Sergey Bulgakov Read Max Weber (1907-1909) // Russian Sociological Review. Vol. 18. № 2. P. 107-119. 
Струве осени 1914 - весны 1915 года, в частности, напр., такое суждение: «Если германская социал-демократия из слепой ненависти к России готова поддерживать прусский милитаризм в его продиктованной безграничным самомнением мировой авантюре, если эта готовность налицо, она означает идейную смерть и духовное разложение германского социализма» (Биржевые Ведомости. 2 изд., № 206, 27.VIII.1914 - цит. по: с. 237).

Вряд ли возможно публицистику первых военных месяцев, где главным аргументом против немецкой социал-демократии оказывается продемонстрированное ею преобладание национальной лояльности над интернациональной классовой солидарностью, рассматривать как глубокое теоретическое суждение. В особенности со стороны национал-либерала, каковым к этому времени стал Струве и для которого, напротив, патриотическая реакция значительной части российской социал-демократии выступала отрадным примером. Другое дело, что в событиях 1917 года и позднее Струве все более политически сдвигался «вправо», но основанием его позднейших оценок немецкой социал-демократии и связанных с этим вопросов никак не могли стать споры по поводу позиции, занятой СДПГ в августе 1914 года.

В целом же приходится сказать, что «новая биография» Струве от Колерова собственно целостной биографией Струве не является - выступая ценнейшим рядом наблюдений и заметок, предполагающих в основании хорошее знакомство читателя с основными жизнеописаниями персонажа ${ }^{8}$. В ней не найти и «портрета» Струве - хотя, если иметь перед глазами его образ, составленный из других источников, книга Колерова даст множество ценных штрихов и новых линий, существенно его меняющих. Так что в итоге приходится пожалеть, что замысел написать именно биографию Струве, пусть и ограниченную 1917 годом, остался нереализованным. Перед нами в итоге retractationes к уже существующему биографическому нарративу, где новую биографию и новый образ Струве предоставляется собирать для себя каждому хорошо информированному читателю самому.

\section{Struve, Retractationes}

\section{Andrey Teslya}

Candidate of Philosophical Sciences, Senior Research Fellow, Scientific Director of the Research Center for Russian Thought, Institute for Humanities, Immanuel Kant Baltic Federal University

Address: Chernyshevsky str., 56, Kaliningrad, Russian Federation 236022

E-mail: mestr81@gmail.com

Book review: Modest Kolerov, Pyotr Struve: revoljucioner bez mass [Pyotr Struve: Revolutioner without Masses] (Moscow: Tsiolkovsky Book Store, 2020) (in Russia).

8. Пайnc P. (2001 [1970]). Струве: биография. Т. 1: Струве - левый либерал. 1870-1905 / Пер. с англ. А. Цуканова, А. Захарова. М.: Московская школа политических исследований; Пайпс P. (2001 [1980]). Струве: биография. Т. 2: Струве - правый либерал. 1905-1944 / Пер. с англ. А. Цуканова, А. Захарова. М.: Московская школа политических исследований; Франк. Указ. соч. 